\title{
Features of 2017A and AISi9Mg aluminum alloys friction stir welded with root-side heating
}

\author{
Właściwości stopów 2017A i AlSi9Mg \\ zgrzewanych metodą friction stir welding \\ z podgrzewaniem grani zgrzeiny
}

\begin{abstract}
Aluminum alloys 2017A and AISi9Mg (hypo-eutectic silumin) were friction stir welded with a relatively high linear velocity (over $1 \mathrm{~m} / \mathrm{min}$ ) and use of an additional heat source from the root side of the weld. Macrostructure investigation (with high-resolution images) showed no effect of heating on weld quality. The welding process caused significant fragmentation of the secondary phases in the AISi9Mg alloy. Furthermore, it was proven that the material above the weld nugget was not mixed and contained micro-defects that were not caused by welding. Also, it contained cavities on the boundaries between Si-particles and the matrix. Based on hardness distribution, a slight strengthening of the cast alloy was observed at the bottom and middle parts of the weld. However, the hardness of the 2017A alloy initially decreased and then increased due to natural aging. This means that the FSW process produced a metastable state in the alloy.
\end{abstract}

Keywords: aluminum alloys, friction stir welding, heating, structure, mechanical properties

\section{Streszczenie}

Stop aluminium 2017A i podeutektyczny silumin AISi9Mg zgrzewano, stosując metodę friction stir welding (FSW). Zastosowano dużą prędkość liniową, powyżej $1 \mathrm{~m} / \mathrm{min}$, oraz dodatkowe podgrzewanie grani zgrzeiny. Badania makrostruktury wykazały brak wpływu podgrzewania na jakość złącza. Proces zgrzewania spowodował znaczną fragmentację faz występujących w stopie AlSi9Mg. Ponadto udowodniono, że materiał występujący powyżej jądra zgrzeiny nie jest mieszany i może zawierać mikrodefekty, które nie powstały w wyniku zgrzewania. Zaobserwowano również nieciągłości na granicach cząstek Si/osnowa. Na podstawie rozkładu twardości stwierdzono niewielkie umocnienie stopu odlewniczego pośrodku dolnej części zgrzeiny. Natomiast twardość

Krzysztof Mroczka Ph.D. D.Sc. Eng., Jerzy Jura Ph.D. D.Sc. Eng.: Pedagogical University of Cracow, Poland; Adam Pietras Ph.D. Eng.: Institute of Welding, Gliwice, Poland; kmrocz@gmail.com 
stopu 2017A najpierw zmalała, a następnie wzrosła w wyniku starzenia naturalnego. To oznacza, że proces zgrzewania wytworzył metastabilny stan tego stopu.

Słowa kluczowe: stopy aluminium, nagrzewanie, struktura, właściwości mechaniczne

\section{Introduction}

Many modern structures, machines, and devices require the use of different, often structurally complex materials such as composites [1], casts [2,3], or materials after plastic forming. All of these materials require joining in different configurations [4]. Traditional fusion joints are subjected to the effects of solidification processes [5] and/or significant changes in the heat-affected zone due to high temperature during the welding process. On the other hand, Friction Stir Welding (FSW) entirely occurs in the solid state [6, 7]. The method involves plastic deformation of welded materials realized by the motion of an FSW tool [8]. Recently, the method has been modified by applying different rates of rotation of the pin and shoulder [9] or using a tool with two shoulders (referred to as a Bobbin-tool). The use of a conventional FSW (basic version) produces an asymmetrical joint that results from a one-way tool motion (rotary and linear). Typically, a weld nugget is observed in the central part, which is a part of the thermo-mechanically affected zone [10]. Usually, a weld nugget consists (wholly or mostly) of the material located on the advancing side. The material flow under these conditions is highly inhomogeneous depending on the location within the weld. This issue has been previously addressed in numerous studies [11-13]. The quality of FSW joints is affected mainly by welding parameters and the shape of the tool $[14,15]$. The paper presents the results of welding two dissimilar aluminum alloys with the use of an additional heat source on the root side, placed along the welding line.

\section{Experimental method}

The 2017A-T451 and AISi9Mg aluminum alloys in the form of wrought and cast plates (respectively) with thickness of $6 \mathrm{~mm}$ were used in this experiment. The chemical composition of the alloys is presented in Table 1. Butt welds were produced parallel to the rolling direction of the 2017A alloy. The welding process was performed with a conventional FSW tool: a pin with the diameter of $8 \mathrm{~mm}$, a shoulder with the diameter of $22 \mathrm{~mm}$, and an angle between the tool shoulder and surface of the welded plates of $1.5^{\circ}$.

Table 1. Chemical composition of 2017A and AlSi9Mg aluminum alloys (wt.\%)

\begin{tabular}{|c|c|c|c|c|c|c|}
\hline Material & $\mathbf{C u}$ & $\mathbf{M g}$ & $\mathbf{M n}$ & $\mathbf{S i}$ & $\mathbf{Z n}$ & $\mathbf{F e}$ \\
\hline 2017A & 4.14 & 0.72 & 0.6 & 0.68 & 0.18 & 0.31 \\
\hline AlSi9Mg & 0.21 & 0.31 & 0.34 & 8.6 & 0.14 & 0.64 \\
\hline
\end{tabular}


The additional heat source was applied - the root side of the welded elements was heated by two heaters, placed parallel and along the welding line (Fig. 1). A temperature of $100^{\circ} \mathrm{C}$ was achieved before the start of the welding operation. TMP (temperature measurement point) is presented in Figure 1. Parameters of welding: the rate of rotation - $560 \mathrm{rpm}$; linear velocity $-1120 \mathrm{~mm} / \mathrm{min}$. The AlSi9Mg alloy was placed on the retreating side.

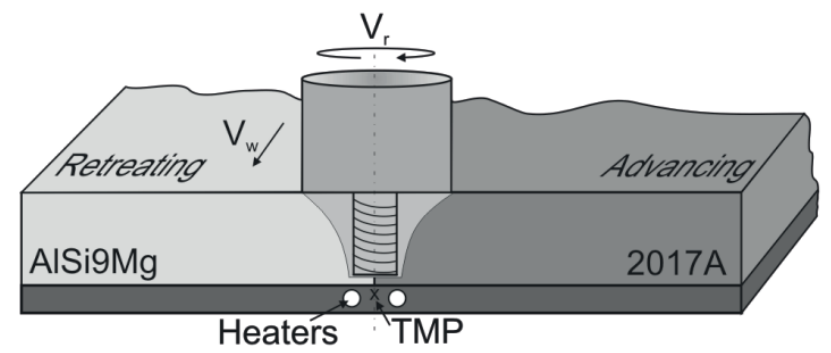

Fig. 1. The schematic representation of the welding process with an additional heat source; TMP - Temperature Measurement Point

The samples were investigated after natural aging (three weeks after welding). The studies of the mechanical properties were carried out to determine hardness profiles $\mathrm{HV}(100 \mathrm{~g})$ at the weld cross-sections. The measurements were taken at distances of $1 \mathrm{~mm}$ from the surface of the weld (the face of the weld).

Scanning electron microscopy (SEM) - a JEOL 6610LV SEM with Oxford EDS detector controlled by AZtec software - was used to investigate the surface of samples (sections). Prior to examination, the samples were mechanically polished.

Microstructure investigations were conducted using an OLYMPUS GX51 light microscope with Nomarski differential interference contrast optics and Stream-Motion software. The light-microscopic observations were performed on surfaces that were mechanically polished and then etched with a solution containing $2 \mathrm{ml} \mathrm{HF,} 4 \mathrm{ml} \mathrm{HNO}_{3}$, and $94 \mathrm{ml} \mathrm{H}_{2} \mathrm{O}$. The macrostructure of joint sections was revealed on the basis of composed microscopic images (magnification $\times 50$ ). As many as 30 to 40 images were combined into one picture of macrostructure by the Image Composite Editor (ICE) software [16]. Analysis of the particle morphology in the AlSi9Mg alloy was conducted on the basis of light microscope microstructure, observed at $\times 500$ magnification on non-etched samples. Particle size and shape factors were calculated using SigmaScanPro5 and Excel Microsoft software.

\section{Results and discussion}

Figure 2 presents the macrostructure of the weld at a higher resolution. The figure also shows the boundaries between the streams of the flowing material (dashed line). These 
boundaries were determined on the basis of a particle distribution pattern. It was revealed that the defects were formed on the boundaries of the streams at the bottom of the advancing side (Fig. 3a). The SEM microstructure (Fig. 3b) shows that material near the defect was deformed in a manner resembling cutting (machining) [17]. On the interior view of the defect, the rake face of a chip $(A)$ and characteristic slip bands on the opposite side (B) could be recognized. The chip indicates that it was likely created in the final stage of tool motion - the tool was just leaving this area (due to linear motion). In areas where friction between the flowing streams of material was sufficient, a good joint was produced (metallurgical continuity of the material). According to various sources, the temperature of the material in the area of the pin's workplace may reach a value from about $400^{\circ}$ to $530^{\circ} \mathrm{C}$, while in the heat affected zone, it reached about $240^{\circ} \mathrm{C}$ on the advancing side and $190^{\circ} \mathrm{C}$ on the retreating side [11]. So, the use of an additional heat source should increase the temperature in the defect-forming area and sufficiently improve the flow of material. Unfortunately, voids formed by the FSW tool were still not filled by the material. Moreover the weld microstructure produced with the same parameters and conditions (but without additional heating) revealed a similar quality of the welds. Both the size of defects and their locations were similar [18].

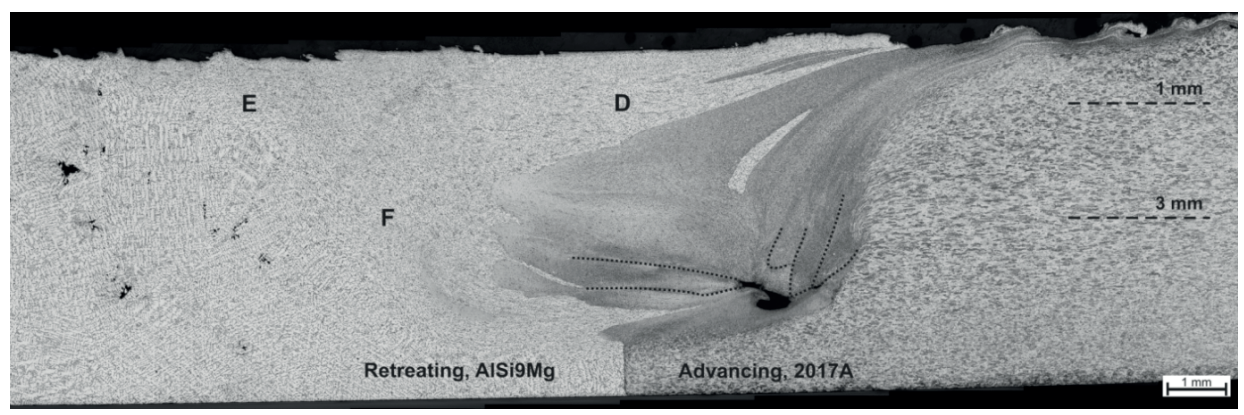

Fig. 2. Macrostructure of cross-section of the weld

a)

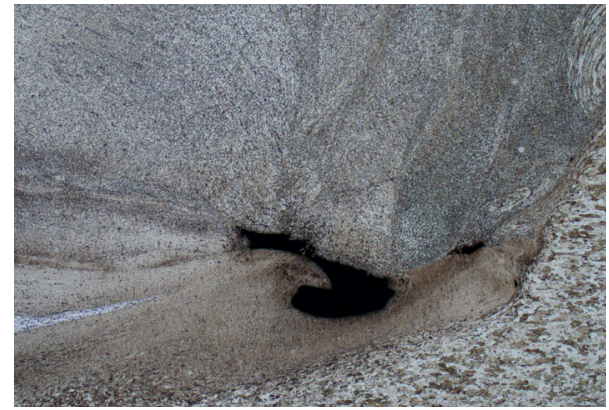

b)

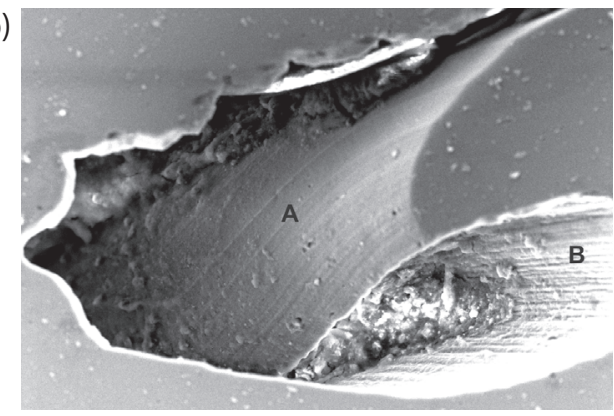

Fig. 3. Microstructure of defects - bottom part of weld nugget, advancing side: a) light microscopy; b) SEM 
The FSW joints produced by the conventional method (i.e., without modification $[9,15])$ have a different microstructure of the weld nugget and the area above the nugget. The inhomogeneity of the microstructure in the tested weld also results from the presence of two significantly different materials. The AISigMg alloy contains particles that are visible by conventional light microscopy. The measurements related to the particle size and their shape factor (SF) allowed for the determination of the degree of microstructure refinement. The eutectic $\mathrm{Si}$ and precipitates with the chemical composition of Al-Fe-Mn-Si were taken into account in the analysis. The $\mathrm{Al}_{15}(\mathrm{FeMn})_{3} \mathrm{Si}$ phase is one of the more-common phases (contains $\mathrm{Fe}$ ) in the as-cast alloys [19]. However, within the tested material (AISi9Mg), the $\mathrm{Al}_{17}\left(\mathrm{Fe}_{3.2} \mathrm{Mn}_{0.8}\right) \mathrm{Si}_{2}$ phase was recognized on the basis of an SEM-EBSD investigation [20]. This phase, along with the eutectic Si phase, was fragmented due to its brittleness. These phases are thermally stable, since they were created as primary particles - they were formed in the liquid phase. Since these particles are stable to the eutectic temperature $\left(577^{\circ} \mathrm{C}\right.$, according to the equilibrium Al-Si binary diagram), their volume fraction should not change during the FSW process, which takes place in the solid state and (i.e.,) at lower temperatures. The investigation showed that the welding produced different areas with significant variations in microstructure: in the middle of the weld (at a distance of $1 \mathrm{~mm}$ from the face) and at the retreating side (at 1 and $3 \mathrm{~mm}$ from the face). These places are marked on the cross section (Fig. 2) by letters D, E, and F, respectively. The results (Tab. 2) show that the largest particle fragmentation occurs in the middle of the weld (region D - Fig. 2). About $88.9 \%$ of the particles have a size of up to $20 \mu \mathrm{m}$, including as much as $63.5 \%$ of the particles with sizes smaller than $5 \mu \mathrm{m}$. This area is mainly deformed by the shoulder, particularly in the final stage of welding. Moreover, significant fragmentation is observed on the retreating side, next to the middle part of the weld nugget (where the material is deformed only by the pin). The largest particles (the smallest refinement) were obtained in areas on the retreating side, near the face. The material there is only deformed by the shoulder. The difference in the average particle size of this area (E) and the area in the center at the same distance from the face (area D) is significant. Regardless of the area within the weld, particle refinement was significant compared to the parent material (where the average particle size was more than ten times greater). Comparing the particle size (in particular areas) to the average value of the shape factor (SF), it should be noted that these results were very similar the SF was about of 0.6 for all of them. The SF value indicates the shape of a polyhedron (value 1 - score for a sphere [21]). The analysis of distributions (histograms) for each SF shows that most particles in the weld have SFs of $0.6-0.8: 59.9,52.7$, and $64.0 \%$ for areas $D, E$, and F (Fig. 2), respectively. However, most particles have an SF of 0.7 (21.9\% - D, $18.8 \%-E$, and $24.5 \%-F$ ). It was noted, however, that oval particles (SF of 0.9 or 1.0) in area $D$ represented $13.4 \%$; in $E-14.9 \%$; but, in area $F$ - only $6.7 \%$. A full histogram for area $\mathrm{D}$ is shown in Figure 4. Figure 5 also shows calculation results for the parent material. The average value of the SF for this material (AlSi9Mg) is 0.48 ; however, the material is dominated by particles with an SF between 0.1 and 0.2 . Particles with these factors 
represent $25.8 \%$, while the total proportion of particles with SFs up to 0.4 is almost half of the total (47.2\%). A full histogram for the parent material is shown in Figure 4. Both the size of the particles and their shapes are radically changed during the FSW process.

Table 2. Analysis of particles in the AISi9Mg alloy - areas in Figure 2

\begin{tabular}{|c|c|c|c|c|c|c|}
\hline \multirow{2}{*}{$\begin{array}{c}\text { Area in } \\
\text { Figure 1 }\end{array}$} & \multicolumn{3}{|c|}{ Area - average } & \multicolumn{3}{c|}{ Shape Factor (SF) - average } \\
\cline { 2 - 7 } & $\begin{array}{c}\text { Value } \\
{\left[\mu \mathbf{m}^{2}\right]}\end{array}$ & $\begin{array}{c}\text { Standard } \\
\text { deviation }\end{array}$ & $\begin{array}{c}\text { Average } \\
\text { deviation }\end{array}$ & Value & $\begin{array}{c}\text { Standard } \\
\text { deviation }\end{array}$ & $\begin{array}{c}\text { Average } \\
\text { deviation }\end{array}$ \\
\hline $\mathrm{D}$ & 8.4 & 16.1 & 9.20 & 0.609 & 0.17 & 0.14 \\
\hline $\mathrm{E}$ & 11.4 & 21.2 & 12.6 & 0.594 & 0.18 & 0.15 \\
\hline $\mathrm{F}$ & 10.4 & 14.5 & 8.9 & 0.582 & 0.15 & 0.12 \\
\hline Parent m. & 87.0 & 203.9 & 107.2 & 0.482 & 0.3 & 0.27 \\
\hline
\end{tabular}

a)

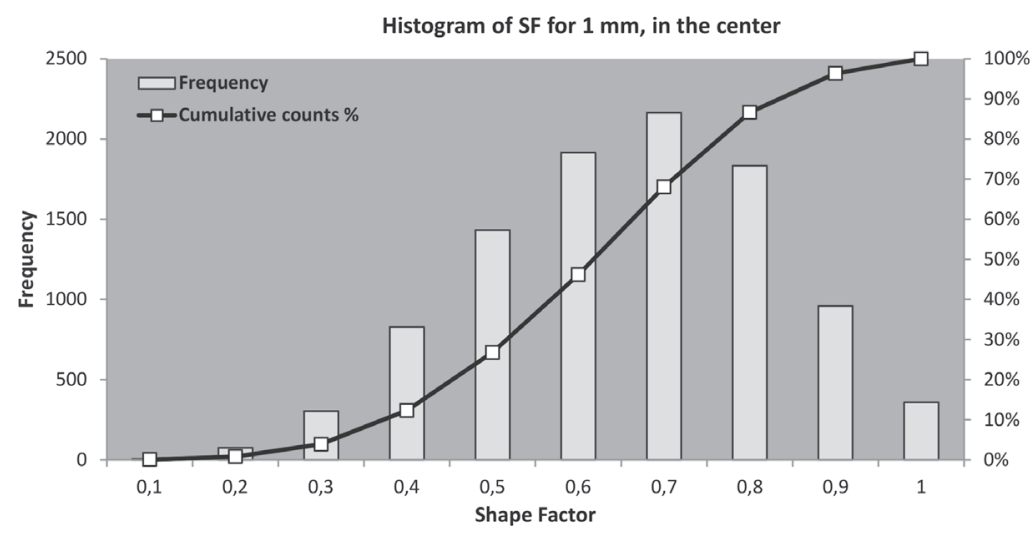

b)

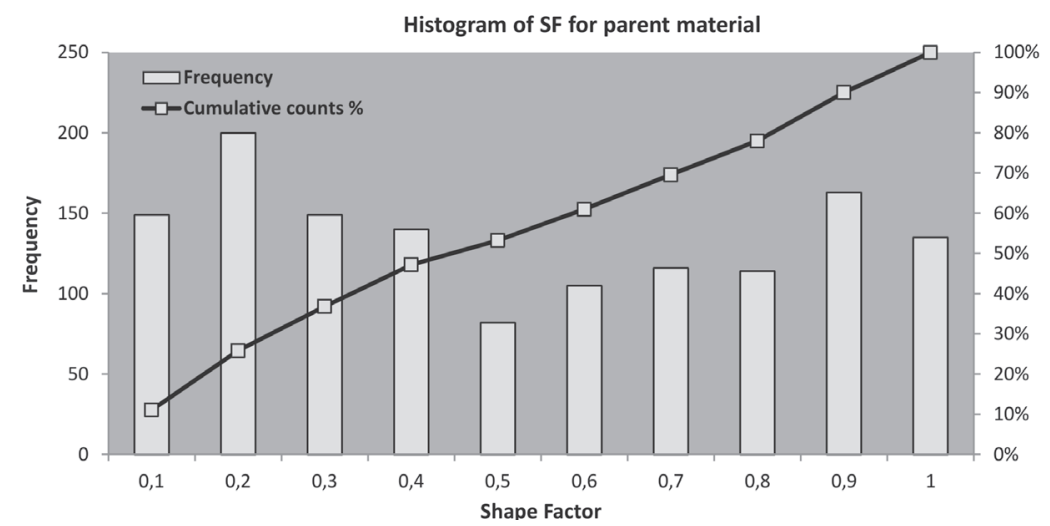

Fig. 4. Histogram of particle Shape Factor: a) for the area placed $1 \mathrm{~mm}$ from the face in the center; b) for the parent material 
The analyzed particles show inhomogeneity in their distribution in the matrix.

The SEM microstructure presents the particles (AI-Fe-Mn-Si) that formed characteristic bands (Fig. $5 \mathrm{a}$ - white particles). This form of arrangement is not accidental, and it is partly related to the direction of material flow in the weld area. The same phase was found within the parent material (AISi9Mg) in the form of a skeletal structure - Figure $5 \mathrm{~b}$ (light grey areas). Due to the plastic deformation (during the welding), the phase is broken into a number of particles and formed in bands. This observation proved that the material in the area above of the weld nugget is not mixed by the FSW tool in the last period of material movement. Micrometer defects (voids) are another aspect of the lack of material mixing, as shown,by the area outlined by a dotted line in Figure 5a (for example). Their presence, in turn, can be associated with defects (referred to as shrinkage [3]) that are present in the parent material (cast). An example of this type of defect is shown in Figure $5 \mathrm{~b}$. It can be assumed that this large defect present in the welding area has not been completely closed (healed) due to the plastic deformation. This means that the amount of plastic deformation in this area was not sufficient for the elimination of all cast defects. Similar observations were also obtained in welds produced under different welding conditions and within the weld of other silumin alloys [22]. The plastic deformation of a material containing a relatively soft and plastic matrix and hard irregularly-shaped particles can produce other type of micro-defects - cavities. These cavities are present at the matrix/particle interface. They are likely caused by the limited plasticity (fluidity) of the material and are mainly due to poor cohesion on the boundary (Fig. 6 - black areas). They are found mainly at the boundary of the eutectic Si/matrix; however, they were also found in grain boundaries. This type of defect is observed in plastically deformed metal matrix materials (e.g., composites) at the matrix/particle interface [23].

a)

b)

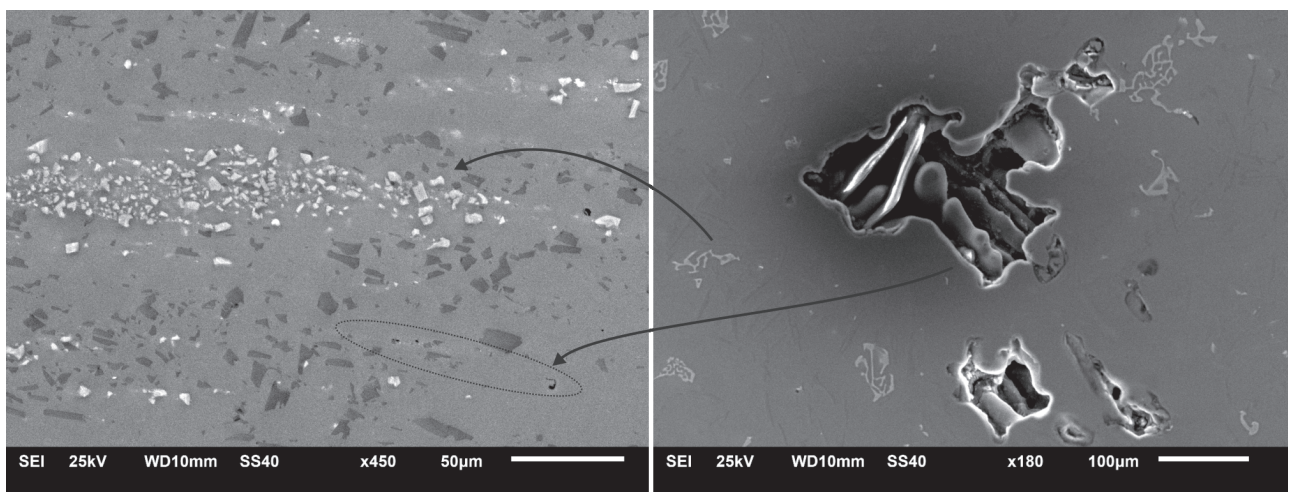

Fig. 5. SEM microstructure; transformation the particle to the band, and shrinkage defect not completely closed: a) $1 \mathrm{~mm}$ from the face (area D in Fig. 2); b) parent material 


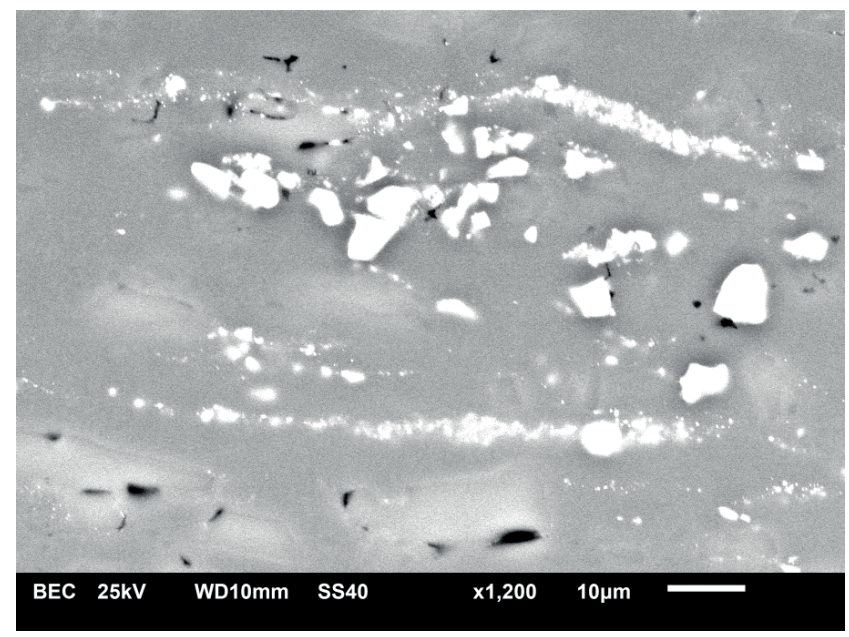

Fig. 6. SEM microstructure - $1 \mathrm{~mm}$ from the face (area D in Fig. 2), defects on particle border

Such a heterogeneous microstructure has different mechanical properties in particular areas. Figure 7 shows the distribution of hardness on the weld cross-section. A considerable spread of hardness values from 53 to $91 \mathrm{HV} 0.1$ at the retreating side (in the heat-affected zone) was observed. This is likely due to the type of microstructure of the cast alloy that contains a relatively soft matrix and harder particles. The average hardness of the area is 66HV0.1, similar to the average hardness of the parent material (63HV0.1). Within the plastically deformed area, the hardness gradually increases to $87 \mathrm{HV} 0.1$. This increase can be explained by the Hall-Petch relationship that was discussed by Yutaka S. Sato [24]. The 2017A alloy is a material with much greater strength and hardness due to the hardening by precipitates containing $\mathrm{Cu}\left(\mathrm{GP}, \Theta^{\prime}, \Theta^{\prime \prime} \mathrm{Al}_{2} \mathrm{CuMg}\right.$ [25]) and microstructure resulting from the rolling process. The FSW process decreased the hardness of this alloy to an average value of 115HV0.1 (134 HV0.1 for the parent material), with a large spread of results that ranged from 103 to $128 \mathrm{HV} 0.1$ (the condition "after welding"). The natural aging process results from an increase in hardness; however, the hardness of the parent material is achieved only locally. The hardness of the plastically deformed area increases (section AB in Figure 7), and its value is approximately equal to the level for the "after welding" condition. It can be assumed that the "base" hardness results from the grain size and state of the matrix. The increase in hardness is an effect of the nucleation of new phases that appear due to the partial supersaturation of the material during FSW. The temperature in the middle of the weld can be as high as $530^{\circ} \mathrm{C}$, and this is an acceptable supersaturation temperature for the 2017A alloy [26]. However, the operating time of heat is too short to cause supersaturation (less than $1 \mathrm{~s}$, considering the high linear velocity $-1120 \mathrm{~mm} / \mathrm{min}$ ), and the dissolution of strengthening particles 
is strongly supported by the large plastic deformation. Elements from dissolving particles are quickly diffused in a strongly defected crystal structure. The significant motion of material also supports the dissolution of the particles. An increase in hardness after aging was also observed in the heat-affected zone, particularly in section BC. It appears that, in higher parts of the weld (the face), the temperature may be slightly higher than in other places due to the large amount of material deformation induced by the pin and also by a shoulder with a significant diameter. This creates conditions for partial dissolution of the phases and, subsequently, the nucleation of fine precipitates, resulting in the hardness increase.

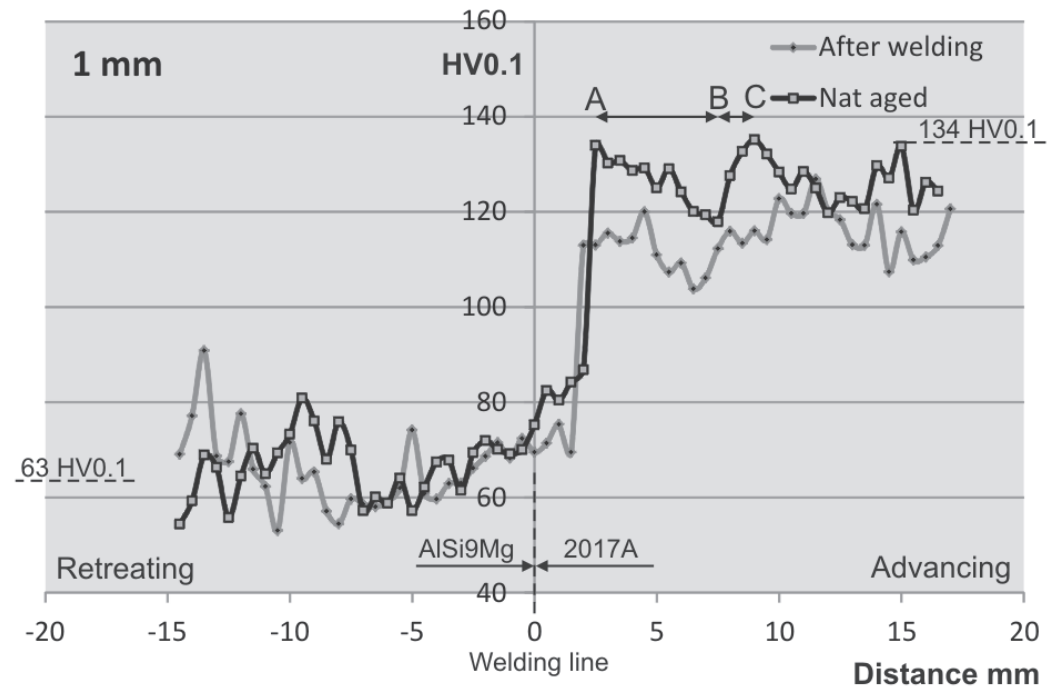

Fig. 7. Hardness distribution on cross-section - $1 \mathrm{~mm}$ from face of weld

\section{Conclusions}

The scope of the experiments and research can be summarized by the following conclusions:

1. The use of additional heating has not changed the quality of the weld. The defects (voids) were not eliminated, and they are located in the lower part of the weld (on the advancing side).

2. The welding process resulted in significant fragmentation of the phases occurring in the AISi9Mg casting alloy - most of the particles have sizes smaller than $5 \mu \mathrm{m}$. The degree of fragmentation is different in different areas of the weld. The fragmentation also changes particle shape from elongated to a polyhedron. 
3. In the area above the weld nugget, the material is not mixed by the FSW tool. The microstructural (pattern) results from a one-directional flow of material. The heterogeneity of this area is mainly due to the presence of local bands containing particles. The amount of plastic deformation in the weld area is sufficient to cause particle fragmentation. but it is too small to remove (close) the shrinkage defects.

4. The hardness of the AISi9Mg alloy slightly increases due to the welding process, but only in the middle part of the weld. The hardness of alloy 2017A significantly decreases. The natural aging caused hardening of this alloy due to the metastable state of the weld immediately after welding.

\section{Acknowledgement}

Partial financing of this research by Ministry of Science and Higher Education, Poland, Research Grants N N508 618940 is acknowledged.

Instrumentation co-financed by the European Regional Development Fund under the Infrastructure and Environment Programme, for the development of the infrastructure and environment.

\section{References}

[1] Fraś E., Janas A., Kurtyka P., Wierzbiński S.: Structure and properties of cast Ni3Al/TiC and Ni3Al/TiB2 composites. PART II. Investigation of mechanical and tribological properties and of corrosion resistance of composites based on intermetallic phase Ni3Al reinforced with particles of TiC and TiB2. Archives of Metallurgy and Materials, 49, 1 (2004), 113-141

[2] Kurtyka P., Ryłko N.: Structure analysis of the modified cast metal matrix composites by use of the RVE theory. Archives of Metallurgy and Materials, 58, 2 (2013), 357-360

[3] Hajjari M., Divandari E.: An investigation on the microstructure and tensile properties of direct squeeze cast and gravity die cast 2024 wrought Al alloy. Materials and Design, 29 (2008), 1685-1689

[4] Uzun H., Donne C.D., Argagnotto A., Ghidini T., Gabaro C.: Friction stir welding of dissimilar Al 6013-T4 To X5CrNi18-10 stainless steel. Materials and Design, 26 (2005), 41-46

[5] Fraś E., Olejnik E.: Interaction between solidification front and alien phase particles. Archives of Metallurgy and Materials, 53, 3 (2008), 695-702

[6] Yeni C., Sayer S., Ertugrul O., Pakdil M.: Effect of post-weld aging on the mechanical and microstructural properties of friction stir welded aluminum alloy 7075 . Archives of Materials Science and Engineering, 34, 2 (2008), 105-109

[7] Węglowski M.S., Pietras A.: Friction Stir Processing - analysis of the process. Archives of Metallurgy and Materials, 56, 3 (2011), 779-788

[8] Kurtyka P., Ryłko N., Tokarski T., Wójcicka A., Pietras A.: Cast aluminium matrix composites modified with using FSP process. Changing of the structure and mechanical properties. Composite Structures, 133 (C) (2015), 959-967

[9] Mroczka K., Pietras A.: Characteristics of dissimilar Friction Stir Welded joints of selected aluminum alloys. Proceedings of Conference: Materials Science and Technology. Pittsburgh PA, USA, Joining of Advanced and Specialty Material, (2012), 308-315 
[10] Shusheng D., Xinqi Y., Guohong L., Bo J.: Comparative study on fatigue properties between AA2024-T4 friction stir welds and base material. Materials Science and Engineering A, 435-436 (2006), 389-395

[11] Adamowski J., Gambaro C., Lertora E., Ponte M., Szkodo M.: Analysis of FSW welds made of aluminium alloy AW6082-T6. Archives of Materials Science and Engineering, 28, 8 (2007), 453-460

[12] Węglowski M.S., Dymek S.: Microstructural modification of cast aluminium alloy AISi9Mg via Friction Modified Processing. Archives of Metallurgy and Materials, 57 (2012), 71-78

[13] Bala Srinivasan P., Arora K.S., Dietzel W., Pandey S., Schaper M.K.: Characterization of microstructure, mechanical properties and corrosion behavior of an AA2219 friction stir weldment. Journal of Alloys and Compounds, 492 (2010), 631-637

[14] Yuan W., Mishra R.S., Webb S., Chen Y.L., Carlson B., Herling D.R., Grant G.J.J.: Effect of tool design and process parameters on properties of Al alloy 6016 friction stir spot welds. Journal of Materials Processing Technology, 211 (2011), 972-977

[15] Węglowski M.S., Pietras A., Węglowska A.: Effect of welding parameters on mechanical and microstructural properties of Al 2024 joints produced by friction stir welding. Journal of Kones Powertrain and Transport, 19 (2009), 523-532

[16] Wójcicka A., Wróbel Z.: The Panoramic visualization of metallic materials in macro- and microstructure of surface analysis using microsoft image composite editor (ICE). Lecture Notes in Computer Science, 7339 (2012), 358-368

[17] Kishawy H.A., Li L., El-Wahab A.I.: Prediction of chip flow direction during machining with self-propelled rotary tools. International Journal of Machine Tools and Manufacture, 46 (2006), 1680-1688

[18] Mroczka K., Pietras A.: Characteristics of FSW welds of aluminum alloys - casted elements with rolled elements. Proceedings of Conference: $9^{\text {th }}$ Friction Stir Welding Symposium, Huntsville, USA (2012)

[19] Mrówka-Nowotnik G., Sieniawski J., Wierzbińska M.: Intermetallic phase particles in 6082 aluminium alloy. Archives of Materials Science and Engineering, 28, 2 (2007), 69-76

[20] Mroczka K.: Characterization of the microstructure and properties of FSW welds of selected aluminum alloys. Scientific Publishing of Pedagogical University of Cracow, Krakow 2014

[21] SigmaScanPro5, User's Guide, 2004

[22] Mroczka K.: The effect of FSW parameters on the microstructure and properties of 2017A/AlSi9Mg aluminium alloy welds. Materials Engineering, 4, 194 (2013), 328-331

[23] Ridley N., Bate P.S., Zhang B.: Effect of strain rate path on cavitation in superplastic aluminium alloy Materials Science and Engineering A, 463 (2007), 224-230

[24] Sato Y.S., Urata M., Kokawa H., Ikeda K.: Hall/Petch relationship in friction stir welds of equal channel angular-pressed aluminium alloys. Materials Science and Engineering A, 354 (2003), 298-305

[25] Genevois C., Fabregue D., Deschamps A., Poole W.J.: On the coupling between precipitation and plastic deformation in relation with friction stir welding of AA2024 T3 aluminium alloy. Materials Science and Engineering A, 441 (2006), 39-48

[26] Mroczka K., Wójcicka A., Kurtyka P.: Acta Metallurgica Slovaca, 18, 2-3 (2012), 82-91 